\title{
INCENTIVES UNDER HYBRID ACTIVITY-BASED COSTING SYTEMS - Case Study -
}

Rainer Lueg, Leuphana University, Germany and University of Southern Denmark, Denmark

\author{
dx.doi.org/10.18374/IJSM-20-1.2
}

\begin{abstract}
The case study at hand deals with a carpenter firm in the luxury segment. The analysis of this case involves a closer look at activity-based costing (ABC) practices that are applied within a hybrid costing system. Top management has decided to leave as much of the old costing system intact as possible, and engages in dialogue with its middle managers why certain changes were necessary. The case also addresses subsequent issues such as changes in transfer pricing between departments. Students are then encouraged to reflect upon the implication of these accounting changes for the incentive provided to middle managers.
\end{abstract}

Keywords: Activity-based Costing; transfer pricing; instructional case study; incentive systems; performance measurement. 